\title{
BRYOGEOGRAPHICAL ELEMENTS OF MOSS FLORA IN GLACIAL CIRQUES "ŚNIEŻNE KOTŁY” (KARKONOSZE MTS.) AND THEIR THREAT
}

\author{
EWA FUDALI ${ }^{1}$, JAN KUČERA $^{2}$ \\ ${ }^{1}$ Department of Botany and Plant Physiology, Agricultural University \\ Cybulskiego 32, 50-205 Wroclaw, Poland \\ e-mail: efudali@ozi.ar.wroc.pl \\ ${ }^{2}$ Faculty of Biological Sciences, University of South Bohemia \\ Branišovská 31, 37005 České Budějovice, Czech Republic \\ e-mail: Jan.Kucera@tix.bf.jcu.cz
}

(Recived: May 27, 2002. Accepted: November 8, 2002)

\begin{abstract}
Based on geographical and ecological analysis of the present moss flora occurring in two contiguous glacial cirques Śnieżne Kotły (Western Karkonosze Mts.), the occurrence of 20 species representing arctic-alpine and subarctic-subalpine elements is discussed.

The majority of (sub)arctic- (sub)alpine elements (70\%) occurred sporadically or very rarely (no more than 5 records), which indicates their general threat. Nine historically recorded species of these geographic elements could not be retrieved during the recent survey, however four of the recently found species have not been found during the systematic survey of historical sites on the Czech, southern, side of Karkonosze Mts. This proves that the northern localization of Śnieżne Kotły cirques favours the survival of relict species.

The question of relictness with respect to the Düll's phytogeographical characterization is discussed; only in ten of the (sub)arctic- (sub)alpine species the relict character could be considered as granted due to their present distribution range.

The full list of the Śnieżne Kotły present moss flora with the brief characteristics of their ecological distribution has been included, first such attempt since 1930 .
\end{abstract}

KEY WORDS: bryoflora, (sub)arctic- (sub)alpine mosses, glacial relicts, threatened bryophytes, Karkonosze Mts., Sudeten.

\section{INTRODUCTION}

The Karkonosze Mts. are the highest range of old middle European mountains situated north of the Alps and from the so-called High Sudeten together with the Hrubý Jeseník Mts. in North Moravia. Due to the geological age the Hercynian elevation seldom exceeds the altitude of 1500 $\mathrm{m}$ a.s.l., and in contrast to Alps the relief is rather smooth and generally lacks rugged rock-faces, deeply cut ravines and precipitous cliffs. It also lacks perennial snow and permafrost (Jeník 1997).

In a common opinion the Hercynian mountains are species-poor and monotonous with respect to their vegetation cover (Jeník 1997; Fabiszewski and Wojtuń 2001). However, there are several species-rich sites, colonized by often biogeographically and ecologically contrasting plant species. According to the anemo-orographic theory formulated by Jeník (1961), high biodiversity at these sites results from their specific topography (usually situated on E-facing flanks), georelief (concave landforms continually subjected to nivation), uneven distribution of snowpack due to wind action and activity of local/orographic topographically generated winds as well as the corresponding leeward turbulence of the near-the-ground winds.

The glacial cirques called "Śnieżne Kotły", situated in the Western Karkonosze Mts., are just such a hot-spot (Limpricht 1930; Jeník 1997). In the past, 113 species of mosses have been reported from there, including 26 taxa (23\%) representing the arctic-alpine and subarctic-subalpine elements (Fudali 2001). It is highly probable that these species came and colonized the studied area together with arctic-alpine tundra during the Late Glacial (Starkel 1977), rather than being later colonists. In the climatic optimum of the late-Atlantic period, when the woodlands expanded towards the topmost summits, the arctic-alpine ecosystems were either destroyed or reduced to sites where snowdrift 
and avalanche action hindered the forest development. Such places are here the glacial cirques (Jeník 1961).

During the last decades, the Karkonosze Mountains have gained a bad reputation due to drastic floristic changes both in the upper forest belt and the subalpine zone, caused mostly by acidification and eutrophication. The decline or loss of many rare vascular plant species and expansion of grasses has been documented e.g. by Fabiszewski and Wojtun (2001). The bryofloristic survey of the summit region of the Eastern Karkonosze Mts. (Czech territory) carried out in 1998-2000 revealed also the probable loss of several taxa, including the arctic-alpine mosses Hypnum callichroum, Hylocomium pyrenaicum, Arctoa fulvella, Polytrichastrum sexangulare, Dicranum elongatum, Grimmia torquata and Kiaeria falcata (Kučera, Buryová 2001). Ironically, the loss referred to some of the best-preserved sites. The latter report induced some questions: how did the global changes affect the bryodiversity of the cirques "Śnieżne Kotły"? Have those changes caused the overall impoverishment of the bryoflora or have the changes affected rather the composition, shifting the proportions of phytogeographical elements or ecological groups? There were no sufficient data to answer these questions so far (Fudali 2001).

Our paper discusses the results of the bryofloristic inventory and ecological observations of mosses within the glacial cirques "Śnieżne Kotły" carried out in years 2000-2002 by the first author. Special attention has been paid to (sub)arctic- (sub)alpine elements but a full list of mosses with brief descriptions of their ecological and spatial distribution has been included, first such attempt since 1930 .

\section{OBJECTS AND METHODS OF INVESTIGATIONS}

The two contiguous glacial cirques "Śnieżne Kotły" are situated on the NW slope of Wielki Szyszak Mt. (Wielki Śnieżny Kocioł - WSK) and on the NE slope of Łabski Szczyt Mt. (Mały Śnieżny Kocioł - MSK). The altitudinal span in the cirques reaches $245 \mathrm{~m}$ in MSK (1175 to 1420 $\mathrm{m}$ a.s.1.) and $240 \mathrm{~m}$ in WSK (1240 to $1480 \mathrm{~m}$ a.s.1.). The geological substratum consists mainly of granite or other very acid silicates, enriched only in the western wall of MSK by a basaltic outcrop.

The bottom of the cirques is covered by moraine granite blocks, which limit the cirques from the North. The vegetation is rather monotonous, created by the dwarf pine growths in MSK (Pinetum mughi sudeticum Matuszkiewicz), and mainly by the tall-grass community dominated by $\mathrm{Ca}$ lamagrostis villosa and Polygonum bistorta in WSK (Crepido-Calamagrostietum villosae (Zlatník) Jeník) (Matuszkiewicz and Matuszkiewicz 1974). The latter community, but with Deschampsia flexuosa replacing the Calamagrostis, covers also the steep walls of the cirques above the dwarf pine shrubs. In wet and shaded places the fern community of Athyrium alpestre has developed. The perpendicular walls lack vegetation of vascular plants, they are covered only with lichens and bryophytes. The upper edges of cirques host the subalpine low grassland with predominant Nardus stricta described as Carici rigidae-Nardetum (Zlatník) Jeník or, at places, with Festuca supina described as subalpine form of Carici rigidae-Festucetum supinae (Jeník) Matuszkiewicz (Matuszkiewicz and Matuszkiewicz
1974). Only locally, in MSK, there are developed patches of other plant communities. The tall-herb community Adenostyletum alliariae Pawłowski, Sokołowski et Walisch along the stream at the cirque bottom and along the water stream flowing from the basalt outcrop, the community with Alchemilla glabra in one of the wet gullies, and a xerothermic low grassland on basalt scree of undefined phytosociological status.

The bryofloristic survey was carried out in years 2000-2001. The bryophytes were collected in small samples from every accessible microhabitat, partly also with use of climbing equipment. Later all specimens were identified microscopically. Ecological notes of substratum, type of vegetation, type of habitat, exposition and altitude (measured with a digital barometric altimeter) were performed. Herbarium specimens (nearly 400) are at present deposited in the first author's collection. Nomenclature of the mosses in the text follows Ochyra et al. (1992), with a few exceptions for which authorities are given in Table 1; the authorities for vascular plants follow Mirek et al. (1995); names of plant communities follow Matuszkiewicz and Matuszkiewicz (1974). The geographical elements for bryophytes were extracted from Düll (1984).

\section{RESULTS AND DISCUSSION}

\section{Geographical analysis of the moss flora}

108 moss species were found during the two years of the field survey; 103 in MSK, 72 in WSK. All of them belong to the Holarctic distribution range and represent 16 geographical range groups distinguished by Düll (1984) (Table $1)$. The most numerous is the boreal-montane range group represented by 34 species $(31 \%)$.

Considering geographical distribution of mosses along climatic zones the studied bryoflora represents five elements: arctic (arctic-alpine range group) - 3 species (3\%), subarctic (subarctic-subalpine range group) - 17 (15\%), boreal (range groups: boreal and boreal-montane) - 41 (38\%), subboreal (range groups: subboreal, subborealmontane) - $17(16 \%)$ and temperate (range groups: temperate, temperate-montane, oceanic-montane, north-oceanicmontane, suboceanic, suboceanic-montane, north-suboceanic, north-suboceanic-montane and subcontinental-montane) $-29(27 \%)$.

With respect to the gradient of oceanity, the core of the cirques' bryoflora does not belong to clear-cut taxa (86\%). Only 12 species belong to the suboceanic element and 2 to the oceanic one (together 13\%), one species represents the subcontinental element.

\section{Frequency and abundance of occurrence}

58 species $(54 \%)$ were noted no more than five times, including 24 ones (22\%) which occurred sporadically. Except for Polytrichastrum sexangulare, which formed a large cushion in a persistent snow bed, the rest of them occurred in scattered patches. 11 species (10\%) were noted 6-10 times, 14 species 10-20 times (13\%) and 25 species (23\%) more than 20 times. Among the latter the most numerous are groups representing the boreal-montane range group - 10 species and subboreal range group - 7 (Table 1).

The proportion of sporadic species within the group of (sub)arctic- (sub)alpine elements was higher than within 
TABLE 1. Ecological character of the present bryoflora of "Śnieżne Kotły" cirques.

Type of vegetation: Ep - specialized epilithic communities, F - fern community with Athyrium alpestre, G1 - grass community with Deschampsia flexuosa and Polygonum bistorta, G2 - grass community with Calamagrostis villosa and Polygonum bistorta, H1 -Adenostyletum alliariae, H2 - community with Alchemilla glabra, P - dwarf pine shrubs, S1 - subalpine low grassland with Festuca supina, S2 - low grassland community with Nardus stricta, Sb thermophilous grassland on basalt.

Type of substratum: B - basaltic rock (exclusively), D - decaying wood, G - granite rock (exclusively), H - humus layer, I - initial soils, P - plant remains, $\mathrm{R}$ - rock (all types), $\mathrm{T}$ - tree bark; $\mathrm{d}$ - dry, w- wet;

Exposure: $B$ - bottom of the cirque, $E$ - eastern, $N$ - northern, $W$ - western, $A l l-E+N+W, B A l l-B+E+N+W$.

Site names: WSK - Wielki Śnieżny Kocioł; MSK - Mały Śnieżny Kocioł.

\begin{tabular}{|c|c|c|c|c|c|c|c|}
\hline \multirow[t]{2}{*}{ Species } & \multirow{2}{*}{$\begin{array}{c}\text { Geographical } \\
\text { element }\end{array}$} & \multicolumn{2}{|c|}{$\begin{array}{l}\text { Number } \\
\text { of records }\end{array}$} & \multirow[t]{2}{*}{ Type of vegetation } & \multirow{2}{*}{$\begin{array}{l}\text { Substra- } \\
\text { tum }\end{array}$} & \multirow[t]{2}{*}{ Exposure } & \multirow{2}{*}{$\begin{array}{l}\text { Altitude } \\
\text { [m a.s.1.] }\end{array}$} \\
\hline & & MSK & WSK & & & & \\
\hline Andreaea nivalis & Arct-alp & 1 & --- & Ep & Gw & $\mathrm{N}$ & 1380 \\
\hline Arctoa fulvella & Arct-alp & 1 & --- & Ep & Gd & $\mathrm{E}$ & 1400 \\
\hline Pohlia ludwigii & Arct-alp & 20 & 3 & $\mathrm{~F}, \mathrm{G} 1, \mathrm{H} 1-2, \mathrm{P}$ & $\mathrm{H}, \mathrm{R}$ & BAll & $1200-1450$ \\
\hline Plagiomnium cf. medium & Subarct-alp & 2 & 1 & $\mathrm{H} 1-2, \mathrm{G} 2$ & Rw, P & $\mathrm{B}, \mathrm{N}, \mathrm{W}$ & $1200-1420$ \\
\hline Pohlia drummondii & Subarct-alp & 5 & 4 & Ep & Gd & $\mathrm{N}, \mathrm{W}$ & $1370-1480$ \\
\hline Polytrichastrum sexangulare & Subarct-subalp & 1 & --- & Ep & $\mathrm{I}$ & $\mathrm{N}$ & 1385 \\
\hline Desmatodon latifolius & Subarct-subalp & 2 & --- & $\mathrm{Sb}$ & Bw & $\mathrm{W}$ & 1370 \\
\hline Ditrichum zonatum & Subarct-subalp & 1 & --- & $\mathrm{Sb}$ & $\mathrm{Bd}$ & W & 1410 \\
\hline Fissidens osmundoides & Subarct-subalp & 1 & --- & Ep & $\mathrm{Bw}$ & W & 1370 \\
\hline Grimmia funalis & Subarct-subalp & 2 & 3 & Ep & $\mathrm{Rd}$ & $\mathrm{N}, \mathrm{W}$ & $1380-1480$ \\
\hline Grimmia incurva & Subarct-subalp & --- & 4 & Ep & $\mathrm{Gd}$ & All & $1360-1480$ \\
\hline Herzogiella striatella & Subarct-subalp & 1 & 2 & $\mathrm{P}$ & $\mathrm{D}$ & $\mathrm{B}$ & 1200 \\
\hline Hylocomiastrum pyrenaicum & Subarct-subalp & 2 & --- & $\mathrm{P}$ & $\mathrm{H}$ & $\mathrm{N}$ & 1250 \\
\hline Hypnum callichroum & Subarct-subalp & 1 & --- & G1 & $\mathrm{H}$ & W & 1260 \\
\hline Kiaeria blyttii & Subarct-subalp & 30 & 20 & $\mathrm{~F}, \mathrm{G} 1, \mathrm{H} 2, \mathrm{~S} 1-2-\mathrm{b}, \mathrm{P}$ & R, H, D & BAll & $1200-1480$ \\
\hline Kiaeria starkei & Subarct-subalp & 25 & 10 & $\mathrm{G} 1, \mathrm{~S} 2$ & $\mathrm{R}, \mathrm{P}$ & All & $1300-1480$ \\
\hline Oligotrichum hercynicum & Subarct-subalp & 20 & 20 & $\mathrm{G} 1, \mathrm{H} 1-2, \mathrm{P}$ & I & BAll & $1200-1480$ \\
\hline Polytrichastrum alpinum & Subarct-subalp & 30 & 30 & $\mathrm{~F}, \mathrm{G} 1, \mathrm{H} 1-2, \mathrm{P}, \mathrm{S} 1-2$ & $\mathrm{H}, \mathrm{P}, \mathrm{R}$ & BAll & $1200-1480$ \\
\hline Ptychodium plicatum & Subarct-subalp & 2 & --- & $\mathrm{Sb}$ & $\mathrm{Bd}, \mathrm{P}$ & W & 1360 \\
\hline Warnstorfia sarmentosa (Wahlenb.) Hedenäs & Subarct-subalp & 1 & 2 & Ep, H2 & $\mathrm{Gw}$ & $\mathrm{N}, \mathrm{W}$ & $1350-1400$ \\
\hline Heterocladium heteropterum & Oc-mont & 4 & --- & Ep & $\mathrm{Rw}$ & W & $1370-1400$ \\
\hline Plagiothecium undulatum & Noc-mont & 1 & --- & $\mathrm{P}$ & $\mathrm{H}$ & $\mathrm{B}$ & 1200 \\
\hline Amphidium mougeotii & Suboc-mont & 2 & 1 & Ep & $\mathrm{H}, \mathrm{Rw}$ & W & 1370 \\
\hline Oxystegus tenuirostris & Suboc-mont & 4 & 1 & Ep & $\mathrm{R}$ & W & $1360-1400$ \\
\hline Plagiothecium platyphyllum & Suboc-mont & 1 & --- & H1 & $\mathrm{P}$ & $\mathrm{B}$ & 1200 \\
\hline Racomitrium aciculare & Suboc-mont & 5 & 10 & Ep, H1 & Rw & All & $1350-1400$ \\
\hline Andreaea rothii subsp. falcata & Nsuboc-mont & --- & 2 & Ep & Gw & W & $1360-1380$ \\
\hline Grimmia donniana & Nsuboc-mont & 2 & 5 & $\mathrm{Sb}, \mathrm{Ep}$ & $\mathrm{Rd}$ & $\mathrm{N}, \mathrm{W}$ & $1380-1480$ \\
\hline Rhytidiadelphus loreus & Nsuboc-mont & 4 & 5 & $\mathrm{G} 1, \mathrm{P}$ & $\mathrm{H}$ & All & $1200-1250$ \\
\hline Brachythecium plumosum & Nsuboc & 4 & 2 & H1 & $\mathrm{H}$ & W & $1300-1350$ \\
\hline Plagiothecium succulentum & Nsuboc & 5 & 2 & $\mathrm{G} 1, \mathrm{H} 1, \mathrm{P}, \mathrm{S} 2-\mathrm{b}$ & $\mathrm{H}, \mathrm{P}$ & $\mathrm{N}, \mathrm{W}$ & $1300-1400$ \\
\hline Rhizomnium punctatum & Nsuboc & 10 & 3 & Ep, H1-2 & $\mathrm{H}, \mathrm{Rw}$ & $\mathrm{N}, \mathrm{W}$ & $1250-1420$ \\
\hline Sphagnum subnitens & Nsuboc & 20 & 5 & $\mathrm{~F}, \mathrm{G} 1, \mathrm{P}$ & $\mathrm{P}$ & BAll & $1200-1480$ \\
\hline Pseudotaxiphyllum elegans & Suboc & 6 & 2 & Ep, H1, P & $\mathrm{H}, \mathrm{Rw}$ & W & $1370-1400$ \\
\hline Andreaea rupestris & Bor-mont & 20 & 20 & $\mathrm{Ep}, \mathrm{P}, \mathrm{Sb}$ & $\mathrm{Rd}$ & BAll & $1200-1480$ \\
\hline Bartramia ithyphylla & Bor-mont & 3 & --- & $\mathrm{Ep}, \mathrm{Sb}$ & Rw & W & $1350-1370$ \\
\hline Blindia acuta & Bor-mont & 1 & 1 & Ep & G & W & $1380-1400$ \\
\hline Brachythecium reflexum & Bor-mont & 30 & 20 & F, G1-2, H1-2, P, S2-b & $\mathrm{H}, \mathrm{P}, \mathrm{R}$ & BAll & $1200-1420$ \\
\hline Brachythecium starkei & Bor-mont & 5 & 10 & $\mathrm{G} 1, \mathrm{H} 1-2, \mathrm{P}$ & $\mathrm{H}, \mathrm{P}, \mathrm{R}$ & $\mathrm{B}, \mathrm{N}, \mathrm{W}$ & $1200-1400$ \\
\hline Cynodontium polycarpon & Bor-mont & 10 & 2 & G1, S2-b & $\mathrm{R}$ & W & $1350-1400$ \\
\hline Dichodontium pellucidum & Bor-mont & 1 & -- & Ep & Bw & W & 1370 \\
\hline Dicranella palustris & Bor-mont & 1 & --- & $\mathrm{H} 1$ & $\mathrm{H}$ & $\mathrm{B}$ & 1200 \\
\hline Dicranella subulata & Bor-mont & 2 & --- & 61 & $\mathrm{H}$ & W & 1350 \\
\hline Dicranodontium denudatum & Bor-mont & 10 & 10 & $\mathrm{G} 1, \mathrm{P}$ & $\mathrm{D}, \mathrm{R}$ & BAll & $1200-1300$ \\
\hline Dicranoweisia crispula & Bor-mont & 10 & 10 & $\mathrm{Ep}, \mathrm{P}, \mathrm{Sb}$ & $\mathrm{R}$ & BAll & $1200-1380$ \\
\hline Dicranum flexicaule Brid. & Bor-mont & 20 & 20 & $\mathrm{G} 1, \mathrm{P}, \mathrm{S} 1-\mathrm{b}$ & $\mathrm{H}, \mathrm{R}$ & BAll & $1200-1300$ \\
\hline Ditrichum heteromallum & Bor-mont & --- & 1 & Ep & I & $\mathrm{N}$ & 1480 \\
\hline Hygrohypnum ochraceum & Bor-mont & 3 & 2 & Ep & Rw & All & $1350-1400$ \\
\hline Hylocomiastrum umbratum & Bor-mont & 1 & --- & $\mathrm{P}$ & $\mathrm{P}$ & $\mathrm{B}$ & 1200 \\
\hline Hypnum lindbergii & Bor-mont & 3 & -- & $\mathrm{G} 1, \mathrm{P}, \mathrm{Sb}$ & $\mathrm{H}, \mathrm{R}$ & $\mathrm{B}, \mathrm{W}$ & $1200-1250$ \\
\hline Mnium spinosum & Bor-mont & 4 & 1 & $\mathrm{G} 2, \mathrm{H} 1$ & $\mathrm{H}$ & $\mathrm{B}, \mathrm{W}$ & $1200-1370$ \\
\hline Paraleucobryum longifolium & Bor-mont & 5 & 10 & Ep, H1, P & $\mathrm{H}, \mathrm{Rd}$ & BAll & $1200-1350$ \\
\hline Philonotis seriata & Bor-mont & 5 & 2 & $\mathrm{Ep}, \mathrm{G} 1, \mathrm{H} 2$ & $\mathrm{P}, \mathrm{Rw}$ & $\mathrm{N}, \mathrm{W}$ & $1350-1400$ \\
\hline Plagiothecium cavifolium & Bor-mont & 10 & 5 & $\mathrm{~F}, \mathrm{G} 1, \mathrm{H} 1-2, \mathrm{P}, \mathrm{Sb}$ & $\mathrm{H}, \mathrm{P}$ & BAll & $1200-1420$ \\
\hline Pogonatum urnigerum & Bor-mont & 20 & 20 & $\mathrm{G} 1, \mathrm{H} 1, \mathrm{P}, \mathrm{Sb}$ & $\mathrm{H}, \mathrm{P}, \mathrm{R}$ & BAll & $1200-1480$ \\
\hline Pseudoleskea incurvata & Bor-mont & 20 & 10 & $\mathrm{~F}, \mathrm{G} 1, \mathrm{H} 1-2, \mathrm{P}, \mathrm{Sb}$ & $\mathrm{H}, \mathrm{P}, \mathrm{R}$ & BAll & $1200-1380$ \\
\hline Racomitrium aquaticum & Bor-mont & 5 & 5 & $\mathrm{Ep}, \mathrm{G} 1, \mathrm{H} 1, \mathrm{Sb}$ & Rw & $\mathrm{N}, \mathrm{W}$ & $1300-1400$ \\
\hline Racomitrium fasciculare & Bor-mont & 20 & 15 & Ep, G1, H1, P, S2-b & $\mathrm{Rw}$ & BAll & $1200-1400$ \\
\hline Racomitrium lanuginosum & Bor-mont & 20 & 40 & Ep, G1, P, S1-2-b & $\mathrm{Rd}$ & BAll & $1200-1480$ \\
\hline
\end{tabular}


TABLE 1. Cont.

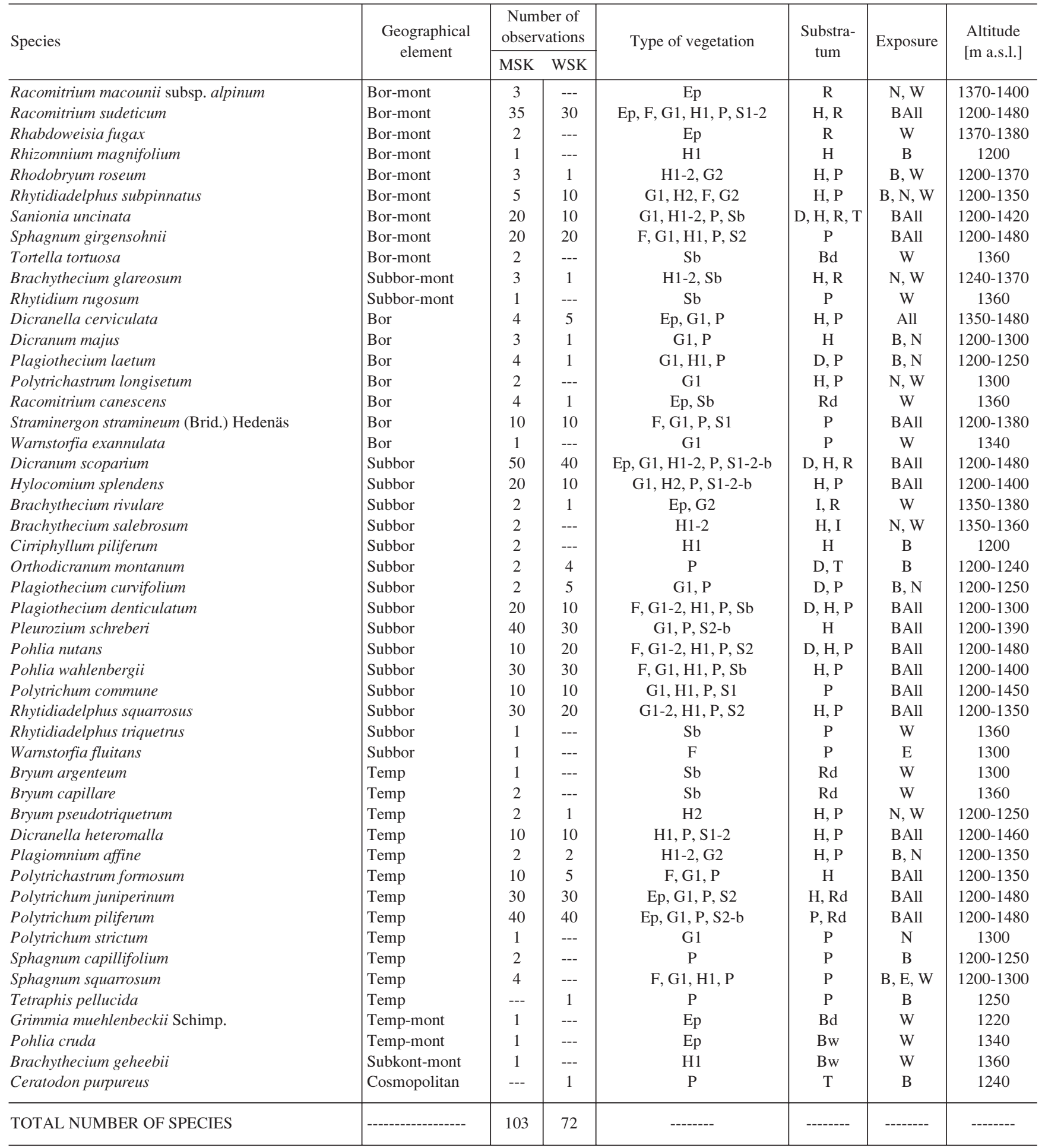

others and reached $70 \%$. Only five species from this group (Kiaeria blyttii, K. starkei, Oligotrichum hercynicum, Pohlia ludwigii and Polytrichastrum alpinum) occurred frequently (were noted more than 20 times) and formed larger cushions. This indicates a high level of threat for those elements and for the glacial relicts among them.

\section{Ecological and spatial distribution}

Considering the criterion of substratum, the majority of species - $59(55 \%)$ belongs to the group of mosses growing on a humus layer or plant remains. 35 species (32\%) were noted directly on rock surface (epiliths sensu stricto), including 9 confined exclusively to basalt and 7 exclusively to granite. The other types of substrata hosted the insignificant number of species: initial soil -5 , decaying wood -4 , tree trunks -2 and multisubstrate -3 .

Within the group of (sub)arctic- (sub)alpine elements the proportion of substratum specialists differs: the group of epiliths dominates with 9 species (45\%), of which four were exclusively associated with basalt, seven species (35\%) occurred on humus and plant remains.

Mosses form independent epilithic communities on rocky walls and boulders or occur within vascular plant communities, often in close relationships with particular phyto- 
coenoses. Most moss species were recorded in Pinus mugo growths -50 ones, with eight exclusive taxa and in Crepido-Calamagrostietum villosae - 46 (4). Rich in moss species were also the epilithic communities - 40 taxa (of which $49 \%$ - 19 taxa were exclusive), followed by the tallforb community Adenostyletum alliariae (39 taxa but only 6 exclusive) and low grassland on basaltic scree - 34 (8). In other vascular plant communities the number of moss species was lower; 21 species were noted in the community with Alchemilla glabra, 18 in the community with $\mathrm{Na}$ rdus stricta, 17 in the community with Athyrium alpestre and 10 in the rest.

Within the group of (sub)arctic- (sub)alpine elements there is a visible socio-ecological specialization - 13 species appeared exclusively in one type of vegetation: seven in the epilithic communities, three in the grassland on basalt, two in the Pinetum mughi sudeticum and one in the Crepido-Calamagrostietum villosae. All of them occurred sporadically or very rarely. Two of the rarely noted subarctic-subalpine moss species were found in two types of vegetation while all the frequently occurring species of this group were noted in two or more types of vegetation. The high number of sites and wide socio-ecological range of the latter indicate the favourable ecological conditions in "Śnieżne Kotły" for their development

The moss flora of the cirques showed also a distinct spatial differentiation. Only 32 species $(30 \%)$ occurred both at the cirque bottom and all the walls. Most species were noted on western walls of cirques - 86 (27 exclusively) and on the northern ones -64 (5). 54 moss species were noted in the bottom of cirques ( 11 exclusively) and 41 on eastern sides ( 2 exclusively). The 11 (sub)arctic- (sub)alpine taxa were limited in their occurrence to the northern and western walls.

\section{Comparison with historical data}

Limpricht (1930) listed 26 moss species belonging to the arctic-alpine and subarctic-subalpine elements. Nine of them were not found presently (Table 2), but the authors suppose that in case of Rhizomnium pseudopunctatum the historical record refers to $R$. magnifolium, which was not recognized earlier. The Limpricht's collection of mosses from Karkonosze Mts. is deposited in the herbarium BP and its revision was not possible within the frame of this project. From the eight other species, particularly Bryum muehlenbeckii and Sphagnum lindbergii are believed to be found during future surveys, given the very common occurrence in similar situations at the Czech side of the range (cf. Kučera and Buryová 2001). The two representatives of Splachnaceae family might occur very temporarily, however, they have not been found even on the Czech side of the range recently. Amphidium lapponicum has recently been found in a very small quantity and sterile on the Czech side and the chance for retrieving this taxon in MSK is also rather high. However, the three remaining species (Dicranum elongatum, Kiaeria falcata and Lescuraea saxicola) might really vanish from the bryoflora of the Krkonoše Mts., as also the situation on the Czech side of the range suggests (Kučera and Buryová 2001).

On the other hand, one species belonging to the arctic-alpine element - Andreaea nivalis (Fudali and Kučera 2002 in press) and two species representing the subarctic-subalpine element - Ditrichum zonatum and Kiaeria blyttii were

TABLE 2. Historical and present-day occurrence of (sub)arctic- (sub)alpine elements in the "Śnieżne Kotły" cirques and their presence in the Czech part of Karkonosze Mts.

Key: WSK - cirque Wielki Śnieżny Kocioł, MSK - cirque Mały Śnieżny Kocioł, b - on basalt outcrop.

\begin{tabular}{|c|c|c|c|}
\hline Species & Historical data & Present-day data & Presence in the Czech part of range \\
\hline 1. Andreaea nivalis & ------- & MSK & Absent \\
\hline 2. Amphidium lapponicum & MSK (b) & ------- & Present \\
\hline 3. Arctoa fulvella & WSK & MSK & Absent \\
\hline 4. Bryum muehlenbeckii & MSK & -------- & Present \\
\hline 5. Desmatodon latifolius & MSK (b) & MSK (b) & Present \\
\hline 6. Dicranum elongatum & MSK, WSK & -------- & Absent \\
\hline 7. Ditrichum zonatum & ------- & MSK (b) & Present \\
\hline 8. Fissidens osmundoides & MSK (b) & MSK (b) & Present \\
\hline 9. Grimmia funalis & MSK, WSK & MSK, WSK & Present \\
\hline 10. G. incurva & MSK, WSK & WSK & Present \\
\hline 11. Herzogiella striatella & MSK, WSK & MSK, WSK & Present \\
\hline 12. Hylocomiastrum pyrenaicum & MSK, WSK & MSK, WSK & Present \\
\hline 13. Hypnum callichroum & MSK, WSK & MSK & Absent \\
\hline 14. Kiaeria blyttii & -------- & MSK, WSK & Present \\
\hline 15. K. falcata & MSK (b), WSK & -------- & Absent \\
\hline 16. K. starkei & MSK, WSK & MSK, WSK & Present \\
\hline 17. Lescurea saxicola & MSK (b) & -------- & Absent \\
\hline 18. Oligotrichum hercynicum & MSK, WSK & MSK, WSK & Present \\
\hline 19. Plagiomnium medium & MSK & MSK, WSK & Present \\
\hline 20. Pohlia drummondii & MSK & MSK, WSK & Present \\
\hline 21. P. ludwigii & MSK & MSK, WSK & Present \\
\hline 22. Polytrichastrum alpinum & MSK, WSK & MSK, WSK & Present \\
\hline 23. P. sexangulare & MSK & MSK & Absent \\
\hline 24. Ptychodium plicatum & MSK, WSK & MSK (b) & Present \\
\hline 25. Rhizomnium pseudopunctatum & MSK, WSK & ------- & Absent \\
\hline 26. Sphagnum lindbergii & MSK, WSK & -------- & Present \\
\hline 27. Tayloria serrata & MSK & -------- & Absent \\
\hline 28. Tetraplodon angustatus & MSK, WSK & ------- & Absent \\
\hline 29. Warnstorfia sarmentosa & MSK, WSK & MSK, WSK & Present \\
\hline
\end{tabular}


newly documented. $A$. nivalis and $D$. zonatum were noted only once while the latter species occurred frequently. It is interesting that Limpricht (1930) has not at all recorded this common species of both cirques; it is very probable that at least some of his records of $K$. falcata will rather belong to $K$. blyttii.

Another interesting point of the present-day data is the occurrence of several (sub-)arctic- (sub)-alpine species that could not be retrieved at their historical sites on the Czech side of the range. These are Arctoa fulvella, Hypnum callichroum and Polytrichastrum sexangulare (Kučera and Buryová 2001). It seems that the northern localization of "Śnieżne Kotły" is more favourable for survival of those species, which can be considered as glacial relicts.

\section{The question of relictness}

There is no doubt that many of the species with northern distribution ranges are the relicts of the last glaciation, which touched the northern slopes of the Karkonosze Mts. The proportion of such species was demonstrated to be extremely high $(64 \%)$, given the relatively low altitude of the cirques. Unfortunately, it is not possible to put a simple sign of equality between the elements evaluated as (sub)arctic- (sub)alpine by Düll (1984) and the glacial relicts. Only the three arctic-alpine species (Andreaea nivalis, Arctoa fulvella, Pohlia ludwigii) and several of the subarctic-subalpine elements (Polytrichastrum sexangulare, Warnstorfia sarmentosa, Desmatodon latifolius, Ditrichum zonatum, Herzogiella striatella, Hylocomiastrum pyrenaicum, Hypnum callichroum) are true upland species, for which the conditions in the cirques represent the lower altitudinal limit in distribution at the present time and their relict character seems to be guaranteed. Nevertheless, the subarctic- (sub)alpine species form a rather heterogeneous group with some of them are rather widely distributed throughout the montane, and rarely even colline belt (Kiaeria blyttii, Fissidens osmundoides, Polytrichastrum alpinum, Plagiomnium medium, Pohlia drummondii). In case of the latter species, we can hardly find any differences against the species evaluated as boreo-montane by Düll (1984), like Blindia acuta, Hylocomiastrum umbratum, Racomitrium lanuginosum or Racomitrium macounii subsp. alpinum. On the other hand, among those „boreal” or ,boreomontane" elements, we can find taxa of markedly less upland or northern character, like Plagiothecium laetum, Racomitrium canescens, Cynodontium polycarpon, Ditrichum heteromallum, Plagiothecium cavifolium, Rhodobryum roseum or even Tortella tortuosa. The relictness of such species cannot be fully excluded, but such status would be quite speculative.

\section{CONCLUSIONS}

1. In the present moss flora of Śniezne Kotły cirques the (sub)arctic- (sub)alpine elements constitute $18 \%$ of the total number of species, of which $10(9 \%)$ can without great reservations be taken as glacial relicts with respect to their present distribution. Their occurrence in the two cirques is not equal - all ten species were noted in MSK and only three in WSK. The "Maly Sniezny Kocioł" cirque can thus be regarded as a particularly important refugium for glacial relicts.
2. The occurrence of the majority of (sub)arctic- (sub)alpine elements $(70 \%)$ is sporadic or very rare (no more than 5 notes), which indicates their general threat. Only five of them: Pohlia ludwigii, Kiaeria blyttii, K. starkei, Oligotrichum hercynicum and Polytrichastrum alpinum were found frequently and can be evaluated as not threatened at present. Except Pohlia ludwigii, all species recognised to be glacial relicts belongs to the group of rare and sporadical thus to the group of presently threatened mosses.

3. The (sub)arctic- (sub)alpine elements showed a visible preference to median and upper parts of the northern and western walls. No pronounced ecological preference could be resolved with respect to the present data.

4. Lack of historical information on frequency and abundance of the glacial relicts' occurrence in the past as well lack of descriptions of their sites (altitude, type of vegetation and substratum, exposure) makes impossible any general quantitative comparison. However, several of the (sub)arctic- (sub)alpine elements found historically could not be retrieved during the present survey (Dicranum elongatum, Kiaeria falcata, Amphidium lapponicum, Bryum muehlenbeckii, Lescuraea saxicola, Rhizomnium pseudopunctatum, Sphagnum lindbergii, Tayloria splachnoides, Tetraplodon angustatus).

\section{ACKNOWLEDGEMENT}

Warm thanks are adressed to Professor Jerzy Fabiszewski who encouraged the first author to study the bryophytes in the "Śnieżne Kotły Cirques".

The research project No. 6PO4C 03419 was supported by the Polish Committee of Sciences in years 2000-2003 and the Czech Ministry of Education grant No. 123100004.

\section{LITERATURE CITED}

DÜLL R. 1984. Distribution of the European and Macaronesian mosses (Bryophytina). Part I. Bryol. Beitr. 4: 1-109.

FABISZEWSKI J., WOJTUŃ B. 2001. Contemporary floristic changes in the Karkonosze Mts. Acta Soc. Bot. Pol. 70 (3): 237-245.

FUDALI E. 2001. Element alpejski i subalpejski we florze mchów polodowcowych kotłów polskiej części Karkonoszy [Alpine and subalpine moss flora of postglacial cirques (Polish part of the Karkonosze Mts.)]. Ann. Siles. 31: 81-88 (in Polish with English summary).

FUDALI E., KUČERA J. 2002. Andreaea nivalis (Andreaeaceae, Musci) new to the Karkonosze Mts. (the Sudeten, SW Poland). Pol. Bot. Journ. (in press).

JENÍK J. 1961. Alpínská vegetace Krkonoš, Králického Sněžníku a Hrubého Jeseníku. Teorie anemo-orografických systémů [Alpine vegetation of the Krkonoše, Hrubý Jeseník and Králický Sněžník Mountains. Theory of anemo-orographic systems]. Naklad. ČSAV, Praha (in Czech with English summary).

JENÍK J. 1997. Anemo-orographic systems in the Hercynian Mts and their effects on biodiversity. Acta Univ. Wratisl. 1950, Prace Instytutu Geograficznego, Ser. C. Meteorologia i Klimatologia 4: 9-21.

KUČERA J., BURYOVÁ B. 2001 '1999’. Bryofloristic survey of the summit region of the Eastern Giant Mts. (Czech Republic). Opera Corcontica 36: 105-132.

LIMPRICHT W. 1930. Die Pflanzenwelt der Schneegruben im Riesengebirge. Englers Bot. Jahr. 63: 1-74, Leipzig. 
MATUSZKIEWICZ W., MATUSZKIEWICZ A. 1974. Mapa zbiorowisk roślinnych Karkonoskiego Parku Narodowego [Map of the plant communities of Karkosze National Park]. Ochr. Przyr. 40: 45-112 (in Polish with English summary).

MIREK Z., PIĘKOŚ-MIRKOWA H., ZAJĄC A., ZAJĄC M. 1995. Vascular plants of Poland: a checklist. Polish Bot. Stud. Guideb. Ser. 15: 1-303.

OCHYRA R., SZMAJDA P., BEDNAREK-OCHYRA H. 1992: List of mosses to be published in ATMOS. In: R. Ochyra, P.
Szmajda P. (eds.). Atlas of the geographical distribution of mosses in Poland., 8, pp. 9-14, W. Szafer Instytut of Botany, Polish Academy of Sciences and Adam Mickiewicz University, Kraków-Poznań.

STARKEL L. 1977. Paleogeografia holocenu [Paleogeography of the Holocene]. PWN, Warszawa (in Polish).

\section{RELIKTY GLACJALNE \\ WE FLORZE MCHÓW REZERWATU ŚCISŁEGO ŚNIEŻNE KOTŁY (KARKONOSZE) I ICH ZAGROŻENIE}

\section{STRESZCZENIE}

W pracy omówiono częstość występowania oraz ekologiczne rozmieszczenie 20 gatunków reprezentujących we współczesnej florze mchów Śnieżnych Kotłów elementy artyczno-alpejski i subarktyczno-subalpejski. Przedyskutowano także problem reliktowego charakteru tych taksonów oraz ich zagrożenia. Przedstawiono też pełny wykaz gatunków stwierdzonych współcześnie w Śnieżnych Kotłach wraz z krótką charakterystyką ich ekologicznego i przestrzennego rozmieszczenia. Jest to pierwsze tego typu opracowanie od 1930 roku.

Większość wysokogórskich gatunków mchów wystąpiła sporadycznie lub bardzo rzadko (nie więcej niż 5 razy) tworząc skąpe darnie, co wskazuje na ich ogólne zagrożenie. Tylko pięć z nich: Kiaeria blyttii, K. starkei, Oligotrichum hercynicum, Pohlia ludwigii i Polytrichastrum alpinum znajdowano często i w większych darniach. Można przyjać, że te nie są zagrożone. Ta grupa mchów wykazuje wyraźne preferencje do występowania w górnych partiach ścian północnej i zachodniej. W większości są to gatunki naskalne.

Biorąc pod uwagę współczesne geograficzne rozmieszczenie mchów, dziesięć gatunków wysokogórskich (elementy (sub)arktyczno- (sub)alpejskie) bez większych wątpliwości można uznać za relikty glacjalne. Są to: Andreaea nivalis, Arctoa fulvella, Desmatodon latifolius, Ditrichum zonatum, Herzogiella striatella, Hylocomiastrum pyrenaicum, Hypnum callichroum, Pohlia ludwigii, Polytrichastrum sexangulare i Warnstorfia sarmentosa. Reliktowy charakter pozostałych taksonów wysokogórskich jest wątpliwy.

Występowanie reliktów glacjalnych w obu Śnieżnych Kotłach jest nierównomierne: w Małym - 10, w Wielkim - 3. Tak więc Mały Śnieżny Kocioł może być uznany za istotne refugium reliktów glacjalnych w Karkonoszach.

Historyczne stanowiska dziewięciu gatunków wysokogórskich nie zostały potwierdzone, natomiast stwierdzono trzy wcześniej nie notowane, w tym jeden nowy dla Karkonoszy: Andreaea nivalis. Cztery ze współczesnie stwierdzonych uważane są za zaginione w czeskiej, południowej, części Karkonoszy. Nasuwa to przypuszczenie, że mikroklimatyczna, północno-wschodnia lokalizacja kotłów po polskiej stronie masywu sprzyja przetrwaniu reliktów glacjalnych.

SŁOWA KLUCZOWE: (sub)artyczno- (sub)alpejskie mchy, relikty glacjalne, zagrożenie brioflory, Karkonosze, Sudety. 